\title{
CT-06 Determinación de habilidad combinatoria de 11 materiales de Theobroma cacao L.
} Determination of combining ability of 11 materials of Theobroma cacao $L$.

\author{
David Alvarado-Güinac*, David E. Moreno-Camey, Julio R. Montesdeoca-Franco
}

Instituto de Investigación y Desarrollo del Sur Occidente, Centro Universitario del Sur Occidente (Cunsuroc), Universidad de San Carlos de Guatemala, Guatemala

*Autor al que se dirige la correspondencia: alvarado77d@yahoo.com

\section{Resumen}

$\mathrm{E}_{\mathrm{p} e r}^{\mathrm{l}}$ 1 cacao criollo es considerado como cacao fino, el cual es más demandado por los mercados internacionales or la diversificación de los subproductos y el valor cultural que buscan los consumidores. Por la demanda de cacaos finos para su establecimiento en parcelas comerciales y la falta de información básica para propagarlos, surge la necesidad de realizar las pruebas de habilidad combinatoria. Esta investigación se realizó en el jardín clonal de la granja docente Zahorí del Cunsuroc, Cuyotenango, Suchitepéquez, con el propósito de generar información de estos materiales. Se consideraron 11 materiales colectados en el territorio nacional. Se realizaron 55 polinizaciones cruzadas y 11 autopolinizaciones, por medio de la metodología de cruzas dialélicas simples con aislamiento de botones florales. Los porcentajes de pegue obtenidos 30 días después de la polinización artificial, fueron analizados por medio de la prueba de $\chi^{2}$ al $0.05 \%$ de significancia y tomándose como intercompatible o autocompatible los materiales cuyos valores fueron mayores al comparador del 30\%. Las cruzas realizadas entre los materiales M1 x M4 (30\%), M1 x M6 (30\%), M1 x M7 (55\%), y M4 x M5 (30\%) se consideran intercompatibles, el material M11 (60\%) se considera autocompatible por que los resultados son iguales o menores al comparador crítico de $\chi^{2}$ = 3.8415. Con base en los resultados anteriores, las cruzas de los materiales M1 x M4, M1 x M6, M1 x M7, M4 $\mathrm{x}$ M5 y el material M11, se recomiendan para futuras investigaciones y ser llevados a plantaciones comerciales por los agricultores.

Palabras claves: Cacao criollo, Suchitepéquez, cacaos finos

\section{Abstract}

$\mathrm{T}$

The creole cocoa is considered as fine cocoa, which is more demanded by international markets due to the diversification of products and its cultural value which is looked by consumers. The demand for fine cocoa for commercial plots establishment and the lack of information to propagate it induced the need to perform the combining ability test. This research was made in the clonal garden of the teaching farm Zahorí from Cunsuroc, Cuyotenango Suchitepequez, in order to generate basic information of these materials. The 11 materials collected at national level were considered. 55 crossbreeding were made and 11 auto-pollinations, through simple methodology diallel crossebreeding by insolating flower buds. The percentages collected were analyzed 30 days after artificial pollination, by $\chi^{2}$ to $0.05 \%$ test of significance and taking as intercompatible or auto-compatible materials which values were greater to the $30 \%$ comparator. The crosses made among materials M1 x M4 (30\%), M1 x M6 (30\%), M1 x M7 (55\%), and M4 x M5 (30\%) are considered intercompatible also the M11 (60\%) material is considered auto-compatible, because the results are equal or less than the critical comparator $\chi^{2}=3.8415$. Based on the prior results, the crossbreeding of M1 x M4, M1 x M6, M1 x M7, M4 x M5 and M11 materials are recommended for further researches and to be taken to commercial plantations by farmers. 